\title{
ESCRIBIR PARA RESISTIR LA SOLEDAD: NOSTALGIA, CONFESIÓN Y AMOR EN CARTAS a Clara de JuAn Rulfo*
}

Fecha de Recepción: 20 de febrero de 2013

Fecha de aprobación: 18 de mayo de 2013

\section{Resumen}

El presente artículo indaga en el conjunto de cartas que el escritor mexicano Juan Rulfo le escribe a Clara Aparicio entre los años 1944 y 1950 las cuales no solo representan un hecho poético en sí mismo, sino que develan al menos tres estados que se conjugan y coexisten en el plano de la expresión de cada misiva: la nostalgia, la confesión y el amor. Por tanto, cada una de las cartas que escribe Rulfo le permite asegurar un lugar en el mundo que empieza a habitar desde la lejanía de su hogar y que comparte de manera permanente con Clara. Juan Rulfo se sustrae de la lógica de la cotidianidad para evaporar la rutinización de su vida en la escritura, podría afirmarse, que como San Juan de la Cruz o Gustavo Adolfo Bécquer, Rulfo se evade en la escritura como oportunidad para albergar un mundo incondicional donde existe él y su corazón, donde existe el sujeto que ama.

Palabras clave: Soledad, nostalgia, confesión, escritura, distancia, amor, Juan Rulfo, Clara Aparicio.

\footnotetext{
* Artículo de Reflexión, producto de la investigación en el curso: “Guimarães Rosa y Juan Rulfo: Literatura comparada y Perspectivismo literario, dirigido por la profesora Maria Candida Ferreira.
}

Citar: Ayram Chede, C. (Julio-Diciembre de 2013). Escribir para resistir la soledad: nostalgia, confesión y amor en Cartas a Clara de Juan Rulfo. La Palabra(23), 79-89.

\section{Carlos Julio Ayram Chede}

Universidad de los Andes, Colombia

carlosayramchede@hotmail.com

Licenciado en Lengua Castellana de la Universidad del Tolima. Estudiante de la Maestría en Literatura de la Universidad de los Andes. 


\section{WRITING TO RESIST SOLITUDE: NOSTALGIA, CONFESSION, AND LOVE IN CARTAS A ClaRA [LETTERS TO Clara] By JuAN Rulfo}

\section{Abstract}

The present article examines the set of letters that the Mexican writer Juan Rulfo wrote to Clara Aparicio between the years of 1944 and 1950, which not only represent a poetic event in themselves, but also reveal at least three states that can be conjugated and coexist in the expression of each letter: nostalgia, confession and love. Each of the letters that Rulfo writes allows him to secure a place in the world that he begins to inhabit while being far away from home, and that he shares permanently with Clara. Juan Rulfo steps aside from the logic of everyday life to evaporate rutine by means of writing. It could be said that, like Gustavo Adolfo Becquer, Rulfo evades reality in writing as an oportunity to give home to an unconditional world, where he and his heart, and well as the subject of his love exist.

Key words: solitude, nostalgia, confession, writing, distance, love, Juan Rulfo, Clara Aparicio

\section{ÉCrire Pour Resister a la SOlITUde: Nostalgie, Confession et amour Dans CarTas a Clara [Lettres a Clara] de Juan Rulfo}

\section{Résumé}

Cet article enquête sur l'ensemble des lettres que l'écrivain mexicain Juan Rulfo écrit à Clara Aparicio entre 1944 et 1950; elles représentent non seulement un fait poétique en soi, mais dévoilent au moins trois états qui se conjuguent et coexistent dans le plan de l'expression de chaque missive : la nostalgie, la confession et l'amour. Donc, chacune des lettres qui Rulfo écrit, lui permet d'assurer un lieu dans le monde qu'il commence à habiter dès l'éloignement de son foyer et qu'il partage avec Clara de manière permanente. Juan Rulfo se soustrait à la logique de la quotidienneté pour évaporer la routinisation de sa vie dans l'écriture; on pourrait affirmer que, comme San Juan de la Cruz ou Gustavo Adolfo Bécquer, Rulfo s'évade dans l'écriture, comme une occasion pour nourrir un monde inconditionnel où il existe lui avec con cœur, où il existe le sujet qu'il aime.

Mots Clés: Soledad, nostalgia, confesión, escritura, distancia, amor, Juan Rulfo, Clara Aparicio 
Ten siempre a Itaca en tu mente.

Llegar allí es tu destino.

Más no apresures nunca el viaje.

Mejor que dure muchos años $y$ atracar, viejo ya, en la isla, enriquecido de cuanto ganaste en el camino sin aguantar a que Itaca te enriquezca. Constantino Kavafis, Ítaca

\section{La partida: algunas consideraciones iniciales}

Si habría de remitirse a un referente concreto sobre Juan Rulfo hoy, gran parte de las respuestas descansarían inequívocamente en sus dos obras más representativas El llano en llamas (1953) y Pedro Páramo (1955). No obstante, una relectura de la vida de Rulfo a la luz de investigaciones sobre su silencio como escritor, después de publicar las que habrían de ser sus obras canónicas, es motivo de grandes interrogantes para la crítica literaria la cual descubre que no solo Juan Rulfo se consagró como narrador, sino como guionista y fotógrafo, hallando producciones estéticas y colaboraciones como El gallo de oro (1960), El despojo (1960) y La fórmula secreta (1964), aparte de un conjunto de fotografías que superan más o menos cuatro mil imágenes de su tierra mexicana. Pero ¿qué sucede cuando la actividad literaria y estética de Rulfo, que se dio con mayor fuerza durante los años cincuenta y sesenta, tiene unos antecedentes en un ejercicio poético, aparentemente menor, que moduló y matizó gran parte de los mundos posibles que construyó Juan Rulfo en Comala, Talpa, Luvina y Jalisco? ¿Qué sucede cuando la escritura del Llano en Llamas y Pedro Páramo, se descubre a la luz de la experiencia individual de Juan Rulfo y se encuentra en los inextricables torbellinos del amor y la nostalgia?

Entre 1944 y 1950, Juan Rulfo ya ejercía una escritura íntima y confesional que lo llevaría a revelar de manera inconsciente la forma como escribiría posteriormente su única novela y su conjunto de cuentos cuya estética está entre la poesía y la oralidad, Juan Rulfo escribe durante siete años de manera constante, podría decirse "tal y como habla", contestando a las cartas de la que sería su esposa en 1948, Clara Angelina Aparicio. A propósito Otto Ricardo comenta que:

Naturalmente, tal estilo da su manotazo a la retórica del habla escrita. Pues el escritor tiene que habituar el grafema al oído, acomodar el sonido de su estilo al de la viva voz de los otros. Ya no puede escribir como él (es un decir) sino como los otros, el común. Con esto, la lengua reivindica sus fueros populares, su casticidad analfabeta y (con pleonasmo) anónima (Ricardo,1985: 165)
Las ochenta y cuatro cartas que escribe hacia Clara, pueden perfectamente constituirse como una primera gesta en su escritura posterior, porque no solo le habla al amor, a su soledad, a su obsesión por la literatura, sino que habla de esos universos convulsionados por una modernización insuficiente que infertiliza a la humanidad y a la tierra. Esta obcecación por la literatura lo es también por la poesía, por el ejercicio de la creación poética. Juan Rulfo fue un asiduo lector de Rainer María Rilke y sus lecturas siempre eran un intento de hacer de las elegías que leía una oportunidad para su estudio y creación "Juan Rulfo tiene que haberse identificado con estas y otras búsquedas [las poesías de Rilke] y hacer sus propias versiones de los diez poemas de Duino. Clara Angelina Aparicio recuerda que su esposo se pasaba alternando los dos extremos del lápiz, estudiando, comparando, descartando, recobrando" (Vital, 2006: 18)

Cartas a Clara no existió como libro ni fue de conocimiento editorial sino hasta el año 2000 cuando fueron compiladas y publicadas ochenta y un cartas donde Rulfo, como un alquimista de la palabra, le expresaba a su esposa el periplo de su amor en tiempos de su trabajo como capataz de una fábrica, como vendedor de llantas y como sujeto consumido por la inclemente soledad. Pero en el año 2012, se publi- 
can en total ochenta y cuatro cartas, tres de estos documentos, una postal, un poema y una carta, que agrupan la totalidad de textos que Rulfo envió a su esposa Clara durante siete años exactos, textos que son en principio una labor de escritura juiciosa en el futuro escritor mexicano y una forma de habitar un lugar propio. Alberto Vital manifiesta que:

Las misivas atestiguan también la importancia del amor y, más adelante, de la familia en la construcción de un mundo propio para quien hará de Comala, de Luvina, de San Gabriel de Talpa, territorios simbólicos, que cerrados y opresivos para los personajes, se abren ya para siempre a los lectores y no dejan de deslumbrarlos (Vital, 2012: 12)

En consonancia con lo anterior, en Cartas a Clara se puede vislumbrar, primero, una expresión de la nostalgia en tanto sufrimiento por el lugar de origen; una orfandad que padece Rulfo y que reemplaza simbólicamente por la madre y las hermanas de Clara ¿Podría decirse que el escritor mexicano emprende un viaje como Ulises hacia Ítaca con la escritura? ¿Acaso hay una relación temprana con lo femenino y la tierra en sus obras? ¿Por qué en sus cartas hay siempre un saludo, ineluctable, hacia la madre de Clara? Rulfo se liga al mito de lo femenino con la presencia de las mujeres que lo rodean y también de las mujeres que más tarde van a ser voces fuera de este mundo como Susana San Juan o la Caponera.

Segundo, el acto confesional emerge de los más profundos devaneos de Rulfo, en su condición como sujeto escritor y lector que le cuenta a Clara lo que fue, lo que quiere ser, los proyectos enigmáticos que tiene por encontrar su casa, la casa de ellos, su enorme afición por los libros, en últimas, la desnuda condición de su alma. La confesión en Rulfo se ve interpelada por las fotografías que se hace tomar para enviar a Clara, pero también de aquellas que son el germen de su afición por el retrato del otro, en este caso, de Clara y su familia.

Tercero, en la expresión poética del amor que fractura esas barreras de los lugares comunes que se dicen usualmente en cartas de amor, hay presencia de ecos y residuos de una escritura romántica. La forma de nombrar al amor se particulariza en las cartas de Rulfo porque hace suyo un sentimiento que comparte con Clara, con Ella, con su amor, con la chachina fea, como la llama en muchas de sus cartas. Rulfo no es el romántico que habla de su amada cuando no está, es claro que en muchas de sus cartas dialoga con ella, le contesta, le habla, le cuenta, la sueña, la llama para sí, la hace suya a través de la escritura.
Desde lejos: Una escritura para resistir a la soledad

Juan Rulfo está solo. Con 27 años parte de Guadalajara hacia ciudad de México para trabajar en la fábrica Goodrich-Euzkadi como capataz lo que lo lleva a separarse temporalmente de Clara. Desde esa distancia empalagosa que se impone como límite geográfico, la carta es el vehículo por excelencia para que establezca una comunicación vital que pueda abolir la distancia. Rulfo sabrá que el mejor ardid para gobernar su mundo y su sentimiento de amor por Clara es entregarse fatigosamente a escribir su experiencia desde lejos, a escribir lo que lo acribilla como ser humano, a escribir en contra de una soledad que se materializa como ser y que termina siendo el único refugio para no sentirse solo. Así lo expresa Rulfo en una de sus cartas "Y la soledad es una cosa que se llega a querer del mismo modo como se quiere a una persona" (Rulfo, 2012: 82).

La comunión que establece Juan Rulfo con la escritura es un pacto de resistencia a la soledad, a la carencia de un Otro que lo acompañe, que lo necesite, que lo saque de esa vida rutinaria que ha asumido, primero como capataz de una fábrica, luego como vendedor de llantas. El tedio, el desasosiego, la inquietud y la enfer- 
medad hacen parte de su itinerario por una vida que está agobiada por las privaciones y la desesperanza de ese mundo autómata y sin sentido que se revela para Rulfo. Dibujar a Clara a través de las cartas con sobres azules que llegan para él, son una fuga de la realidad que padece y que lo acecha aún viviendo y reafirmándose en el campo de la escritura. Así le expresa Rulfo ese sentimiento a Clara:

No sé, a veces me pongo a
pensar que tengo que venir a
vivir aquí, siento un cosqui-
lleo muy raro en el estómago
(tú ya sabes que esas cosqui-
llas son mi falta de decisión)
y es que ya siento extraña la
vida aquí, o tal vez porque tú
has hecho que Guadalajara
sea lo que antes de cono-
certe no era para mí. Aun-
que.... Ahí está el aunque.
(Rulfo, 2012: 44-45)

Las cartas que contesta a Clara acaban con la soledad que lo persigue y le posibilitan a Rulfo construir un Otro que está ausente pero presente en tanto está prefigurado por la escritura. Octavio Paz sostiene que:

La soledad es el fondo último de la condición humana, el hombre es el único ser que se siente solo y el único que es búsqueda de otro. $\mathrm{Su}$ naturaleza- si se puede hablar de naturaleza al referirse al hombre, el ser que precisamente, se ha inventado a sí mismo decirle "no" a la naturaleza- consiste en aspirar a realizarse en un otro" (Paz, 2012:211).
Rulfo construye un alter ego que es su corazón, el que siente, él confiesa que ama con locura a Clara, pero también constituye la presencia de Clara a través de la escritura. De un lado, su escritura está impregnada de los dictámenes de su corazón pero también de la re-presentación que hace constantemente de su amada para justificar no solo la existencia de su amor sino un tipo de compañía que se abate perennemente contra la soledad. Rulfo le expresa a Clara que "La carta esta última que escribiste tenía dinamita. Pero también tenía algo, no sé qué sería, que me hizo sentir que estabas tú muy cerca de mí, que estabas aquí conmigo y que no me abandonarías jamás" (Rulfo, 2012:123).

De otro lado, hay una ansiedad que devora a Rulfo al no tener conocimiento de las cartas de Clara, no solo porque son contestadas cuando son recibidas por el escritor mexicano, sino porque la llegada de las cartas le justifica que no está solo, que esa soledad no lo puede engullir, no puede acabar con él. "Lo que quisiera en el fondo es que quisiera tener una carta tuya cada cuarto de hora. Por más que las leo no me lleno" (Rulfo, 2012,139), y es que las cartas de Clara, dice Juan Rulfo, son muy cortas, no alcanzan a saciar ese apetito por la compañía deseada. La síntesis de Clara, en contraposición a la extensión de la cual hace alarde Rulfo, poseen una relación dialéctica que tienden a llevar a la soledad a su límite, de inflarla con el helio de la pasión, estallarla con las espinas de un amor distanciado y en ocasiones corajudo.

Tal vez sería un lugar común decir que Rulfo escribe con el corazón, destila su sentimiento de amor en cada una de los párrafos de sus cartas y es lo que hace excepcional y bello el acto mismo de la escritura. Rulfo quiere vagabundear fuera de ciudad de México y de los lugares en los cuales escribe para llegar a Guadalajara. La escritura de las cartas es una necesidad de viaje simbólico, de caminata errabunda que transporta, sin llegar a ser esencialistas, su amor y corazón. Al respecto Gastón Bachelard afirma que "[C]on frecuencia es en el corazón del ser donde el ser es errabundo. A veces es fuera de sí donde el ser experimenta consistencias. A veces también está, podríamos decir, encerrado en el exterior. Daremos después un texto poético donde la prisión se encuentra en el exterior" (Bachelard, 2005:188. La soledad para Rulfo consiste en una prisión de dimensiones ingentes que solo puede trasgredir cuando cada una de las páginas que envía a Clara es un latido de su corazón enfermo por la nostalgia. Así lo escribe Rulfo: "A veces imagino que hace ya tiempo que te casaste conmigo y que estás de vacaciones allá en tu casa y que pronto volverás y entonces ya 
no me separaré de ti. A veces pienso eso. Así no me siento tan solo" (Rulfo, 2012:73)

Si bien la escritura de cada carta es también un acto incorpóreo, resistir a la soledad es también evadirse de la realidad para entregarse a la escritura, la meditación y el reino de lo onírico. Juan Rulfo escribe desde una habitación que alquila en ciudad de México y desde allí su aquelarre será continuo con la escritura. Bécquer escribe desde su celda en un monasterio, San Juan de la Cruz en sus delirios místicos escribe desde su celda en una cárcel. Los tres escriben desde la prisión de la realidad, de la soledad y el desencanto. Los tres se sustraen como seres materiales y en cambio se materializan en su propia escritura. Juan de la Cruz escribe:

\section{¡Oh, llama de amor viva, que tiernamente hieres de mi alma en el más pro- fundo centro! \\ Pues ya no eres esquiva, acaba ya, si quieres, rompe la tela des 'te dulce encuentro.}

De otra parte, Bécquer escribe lo siguiente:

Queridos amigos: Heme aquí transportado de la noche a la mañana a mí escondido valle de Veruela; heme aquí instalado de nuevo en el oscuro rincón del cual salí por un momento para tener el gusto de estrecharos la mano una vez más, fumar un cigarro juntos, marchar un poco y recordar las agradables aunque inquietas horas de mi antigua vida. Cuando se deja una ciudad por otra, particularmente hoy que todos los grandes centros de población se parecen, apenas se percibe el aislamiento en que nos encontramos, antojándosenos al ver la identidad de los edificios, los trajes y las costumbres, que al volver la primera esquina vamos a hallar la casa a que concurríamos, las personas que estimábamos, las gentes a quienes teníamos costumbres de ver y hablar de continuo (Bécquer, 2012: 1).

Rulfo por su parte le escribirá a Clara

\begin{abstract}
Entonces me llegan unos remordimientos de conciencia muy feos, cada que pasa un día y otro y no sucede nada. Y este ir tan despacio me desespera mucho. Yo estoy seguro de que Dios si trata de ayudarme, pero quizá yo no pongo nada de mi parte. Y si tú supieras cuán insensato e irresponsable me siento calcularías mis remordimientos. $\mathrm{Y}$ no me sentiré conforme hasta el día en que logre caminar sobre un camino que yo sepa que es el de mi voluntad. Y que ese camino vaya a dar a donde tú estás (Rulfo, 2012:97)
\end{abstract}

En los tres ejemplos hay una cohesión indiscutible en términos de la escritura. Cada uno de estos escritores, que aunque los separan momentos históricos y contextos diferentes, comparten esa alianza con la dimensión de la escritura en contra de una soledad que los embarga, que viene desde fuera y que los quiere implicar en una realidad que es ajena a la realidad que ellos experimentan. En el caso de Juan de la Cruz hay una profunda evasión en términos místicos, en Bécquer una necesidad de reconciliarse con la naturaleza y en Rulfo un profundo apego por Clara, territorio de paz, de "claridad", de voluntad y virtud. En últimas, la evasión en la letra es una evasión en el amor, sea este místico, sentimental o sencillamente muy humano.

La escritura de la carta también es un aviso de invitación a la meditación. Gaston Bachelard sostiene que "Mediante la soledad se devuelve al filósofo [en este caso al escritor] al destino de la mediación primigenia. Mediante la soledad tiene la meditación toda la eficacia de la admiración" (Bachelard 2005:239), lo que nos lleva a comprender que así haya una resistencia hacia la soledad como carencia de otro, esta provee de un espacio para el encuentro consigo mismo, con el otro que se dibuja en las cartas y con los pensamientos más primigenios que acechan al ser humano. Rulfo entra en una dialéctica, la de la soledad, como lo explicita Octavio Paz "La soledad es una pena, esto es, una condena y una expiación. Es un castigo, pero también una promesa del fin de nuestro exilio. Toda vida está habitada por esta dialéc- 
tica” (Paz, 2012: 212). Rulfo se resiste a la soledad pero a la vez la desintegra en un acto de soberbia escritural; de manera paradójica, se escapa de la soledad pero habita esa soledad.

Por último se encuentra la reconciliación entre el acto de la escritura y el reino de lo onírico, donde opera de manera explícita el ensueño como umbral de la expresión del ser. Los recuerdos que empapan cada una de las páginas que Rulfo le escribe a Clara hacen que exista la inmensidad de las imágenes, de su sentimiento, de su condición como ser humano. Volviendo a Gaston Bachelard (2000:164):

La inmensidad está en nosotros. Está adherida a una especie de expansión de ser que la vida reprime, que la prudencia detiene, pero que continúa en la soledad. En cuanto estamos inmóviles, estamos en otra parte; soñamos en un mundo inmenso. La inmensidad es el movimiento del hombre inmóvil. La inmensidad es uno de los caracteres dinámicos del ensueño tranquilo.

Rulfo se adhiere a su escritura y es en ella donde se nos revela la inmensidad de su lenguaje, las múltiples formas para hablar y nombrar al amor, las formas inagotables para expresarle a Clara cuanto la ama. "Y solo el pensamiento de que tú existes me quita esa tristeza y esa fea amargura" (Rulfo, 2012:51).

\section{Una Ítaca poblada por la escritura: aquello que nos dice el nostos}

Las cartas que Juan Rulfo le escribió a Clara Aparicio pueden también ser expresiones de nostalgia. Según Milan Kundera en la novela La ignorancia "En griego, «regreso" se dice nostos. Algos significa «sufrimiento». La nostalgia es, pues, el sufrimiento causado por el deseo incumplido de regresar" (Kundera, 2005: 5) Guadalajara representa para Juan Rulfo una Ítaca donde se encuentra Clara, esperando siempre la respuesta de las cartas y escribiendo a la vez para que a Rulfo lo acompañen sus palabras desde la distancia.

El nostos para Rulfo es ese tiempo en el que vive separado de Clara, una imposibilidad por el regreso, por tanto, hace de esa Ítaca que es Guadalajara un hogar para él y su amada. El nostos representa una empresa en Rulfo que está vacía de toda presencia física para llenarse con la escritura, para poblarlo con la letra como única posibilidad de conexión con su "chachina" fea y odiada. Así lo expresa Juan Rulfo "Dices que te extrañó mucho que te haya escrito con mucha rapidez. Yo siempre te escribo muy rápido. Pero yo creo que a veces el correo no reparte aprisa las cartas y las deja dormir y por eso nos las recibes luego luego. De cualquier modo, a mí me gustaría poder llevártelas yo mismo o meterme adentro del sobre para asomarme y verte cada vez que te escribo. Eso es lo que yo quisiera" (Rulfo: 2012:147).

Leyendo las ochenta y cuatro cartas de Juan Rulfo se puede sentir el dolor que causa la distancia y la angustia por escribir siempre cartas-periódico que dan cuenta de todo lo que pasa, de todo acontecimiento por anodino que resulte, de cada sentimiento que despierta pensar en Clara en cualquier momento del día. Ese Algos griego, el sufrimiento, se incrementa en la imposibilidad del regreso, pero se escapa del mismo cuando hay una carta escrita, cuando se comunica, a veces, lo que no tiene nombre, cuando se intenta amar en la palabra a Clara, cuando escribe cartas con imágenes, cuando las formas de escritura se alteran y forman una especie de caligrama que en secreto se le dirige a la persona amada; estas son las claves de un lenguaje que implica el amor por el origen, el deseo y la paciencia por el regreso. En la siguiente imagen se puede apreciar ese juego con la escritura:

La nostalgia que atraviesa a Rulfo y hace de su ejercicio escritural que deviene de ese contacto con la soledad es "[n] ostalgia de un cuerpo que fuimos arrancados, es nostalgia de espacio. Según una concepción muy antigua y que se encuentra en casi todos los pueblos, ese espacio no es otro que el cen- 


\section{la palabra}
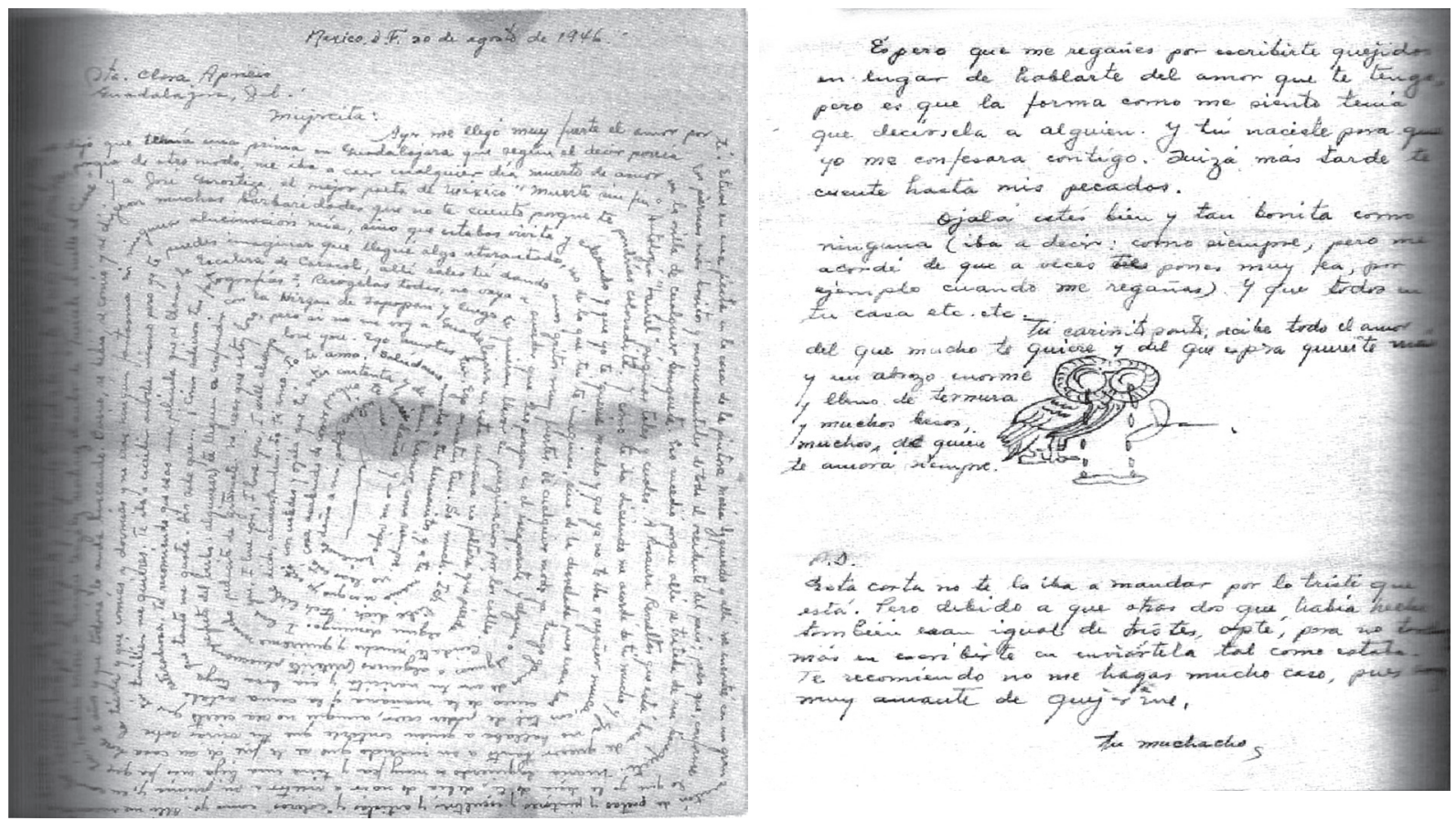

Imágenes recuperadas de la edición de Cartas a Clara de RM editorial.

tro del mundo, el "ombligo del universo" (Paz, 2012:226). Ese cuerpo y ese centro del mundo, para Rulfo es la tierra, de la cual es huérfano en esa imperiosa ciudad de México donde solo ve fábricas y procesos de modernización. Rulfo se liga a la tierra y liga a sus mejores personajes de sus obras con la tierra, con la dimensión materna, con la que está allí para recibir siempre a sus hijos cuando estos vuelvan como pródigos de lo que les prometieron en la ciudad.

Para Rulfo, Guadalajara además de ser Ítaca es su centro, su ombligo, el lugar donde puede estar a gusto con Clara, donde puede construir una geografía sagrada y familiar, en términos más cotidianos, del lugar de dónde se es. "Me he acordado mucho de ti. Todo el camino me viene piense y piense que en Guadalajara se había quedado una cosa igual a las cosas que andan por el cielo, y de puro acordarme veía sonriéndome mi corazón y dando de a brincos a cada paso, como si no le cupiera el gusto de saber que tú existes. Debido a eso no se me hizo largo el camino" (Rulfo, 2012: 25)

Ese sentimiento de nostalgia por la tierra, Rulfo lo transporta en las imágenes de las mujeres. La madre de Rulfo muere cuando él tiene 12 años y esa pérdida lo va a marcar toda su vida, porque el sentimiento de orfandad estará siempre presente, en su nostalgia también por la dimensión de lo materno. Inclusive, Juan Rulfo apoda mucho a Clara Aparicio en los encabezados de las cartas, siempre re- firiéndose a ella como chiquita, mujercita, chanchina, Mayecita, Kiko, madrinita, entre otras expresiones que particularizan la forma como Rulfo llama a su amada pero que le entregan casi un papel de madre sustituta en la relación afectiva que los une. Este fragmento ilustra lo anterior "Clara, mi madre murió hace 15 años; desde entonces, el único parecido que he encontrado en ella es Clara Aparicio, alguien a quien tú conoces, por lo cual vuelvo a suplicarte le digas me perdone si la quiero como la quiero y lo difícil que es para mí vivir sin ese cariño que ella tiene guardado en su corazón” (Rulfo, 2012:29)

Pero la otra relación que establece Rulfo en sus cartas con las mujeres es con la madre y las hermanas de Clara. Las 
despedidas de las cartas siempre terminan con frases como "salúdame mucho a tu mamacita” (Rulfo, 2012:41) “[a] esa mamacita tan buena que tienes" "[y]o iré el domingo próximo a ver a la virgen de Guadalupe y le pediré por tu mamacita y por nosotros por este par de chachinos tontos". Y aunque no haya un saludo explícito a la madre de Clara, siempre hay un saludo indirecto, como si fuera una preocupación constante también para Rulfo saber que ella se encuentra bien. Sin llegar a lecturas psicoanalíticas innecesarias, Rulfo tiene una fijación particular con la figura materna, porque firma en algunas cartas siempre como "Juan Tu muchacho", "tu hijo Juan" o "tu adorado hijo Juan", fijación que llega hasta la imagen de Dolores Preciado, Dorotea, la Caponera, Felipa, Damiana Cisneros y Eduviges, por nombrar algunas.

\section{Confieso que confieso mis locuras y mi amor}

Las cartas a Clara Aparicio escritas por Juan Rulfo durante siete años, pueden catalogarse como siete años de confesiones, siete años donde se reafirma el amor. La escritura genera un espacio indiscutible donde Rulfo se revela como Rulfo, no como escritor, aunque muchas de sus cartas de manera constante apelan a unas formas poéticas que confirman la vena que como escritor iría a tener y también la forma escueta de la oralidad como recurso pri- mordial para la construcción de sus obras. "Hoy se murió el amor por un instante y creí que yo también agonizaba/ Fue a la hora en que diste con tus manos aquel golpe en la mitad del alma/y que dijiste: tres años, como si fuera tan larga la esperanza” (Rulfo, 2012:23)

La escritura de las cartas es un espacio que se habita en la medida en que se confiesan las locuras, los ensueños, los proyectos de una vida que Rulfo quiere vivir con Clara. El espacio de la escritura rehace a Rulfo lejos de una rutinización insulsa que él mismo va a leer como una promesa de modernidad que está en la ciudad pero no en las periferias rurales de México. Escribir para Rulfo es librar cientos de batallas con su realidad y es la única forma que tiene, en ese momento de distancia de Guadalajara y de Clara, para expresar lo que ve, lo que siente, lo que imagina. "Ellos no pueden ver el cielo, viven sumidos en la sombra, hecha más oscura por el humo. Viven ennegrecidos durante ocho horas por el día o por la noche, constantemente, como si no existiera el sol ni nubes en el cielo para que ellos las vean, ni aire limpio que ellos lo sientan. Siempre así e incasablemente como si solo hasta el día de su muerte pensaran en descansar" (Rulfo, 2012: 51)

La confesión tiene un carácter triple en la escritura de Juan Rulfo. En primer lugar, hay una confesión sobre el te- dio que representa su trabajo, el deseo de salir corriendo de las tinieblas de la fábrica Goodrich-Euzkadi que pareciera que lo envolviera como a los obreros que describe en algunas de sus cartas. La confesión más que un acto de contrición, en términos religiosos, es un acto contrito de la vida que ha sobrellevado lejos de Clara, pues es ella la única que le permite a Rulfo existir sin desparecer en el violento ambiente de la fábrica.

La confesión funciona también como un proyecto trasgresor de la realidad que viven los amantes distanciados; es el pensamiento de Rulfo siempre tratando de poblar con la escritura un lugar que esté más allá de lo impuesto por esa separación detestable que les ha tocado vivir. Rulfo le expresa Clara:

\footnotetext{
Siempre he creído que uno debe aceptar la vida tal como es, pero siempre y cuando no tenga remedio. En este caso es distinto; hay algo que nos separa a ti y a esa otra criaturita de mí y uno tiene que luchar por lo que más quiere. Entonces ese algo hay que destruirlo; entre tú y yo, podemos destruir lo que nos impide estar en nuestra casa y busca la manera de ayudarnos el uno al otro (Rulfo, 2o12:269).
}

En segundo lugar, la confesión, siguiendo a María Zambrano tendría una relación estrecha e íntima con la fundación del sujeto, lo cual es po- 
sible rastrear en todas las cartas de Rulfo, porque no solamente está enunciado a Clara, sino que se enuncia a sí mismo y enuncia su mundo. Al respecto Zambrano nos dice que "La Confesión es el lenguaje de alguien que no ha borrado su condición de sujeto; es el lenguaje del sujeto en cuanto tal. No son sus sentimientos, ni sus anhelos siquiera, ni aun sus esperanzas; son sencillamente sus conatos de ser. Es un acto en el que el sujeto se revela a sí mismo, por horror de su ser a medias y en confusión" (Zambrano, 2004: 29). Ser sujeto en tanto se enuncia y es enunciado permite abrir las posibilidades humanas que tienen las cartas de Rulfo, que una vez más confirman, lo cual puede sonar a lugar común, su condición humana. Pero ese acto confesional también está ligado a su cotidianidad, es decir, a lo que él como sujeto piensa de su devenir por la vida, de sus proyectos futuros, de la compra de una casa para Clara y él, del amueblamiento de su departamento, de su deseo de ser librero, de abrir una librería donde sea y con los dineros del rancho de sus padres. Así se le confiesa Rulfo a Clara en un pasaje de sus cartas su vida en un departamento:

Niñita, la casa donde vamos a vivir tienes tres piezas, la cocina y el baño, todo tamaño miniatura, como son los tales apartamentos. El día menos pensando, sin embargo podremos encontrar algo mejor y más grande.
(...) también te quería decir esto: que los apartamentos que tienen ventanas a la calle son más chicos, de dos piezas nada más, pero a pesar de todo me gusta porque no hay que estar viendo el cielo por esos agujeros que llaman ventanas, y el otro cielo que eres tú iluminado por el sol que entre allí. Ya encargaron que cuando se desocupe algunos de ésos me lo den. (Rulfo, 2012: 176-177)

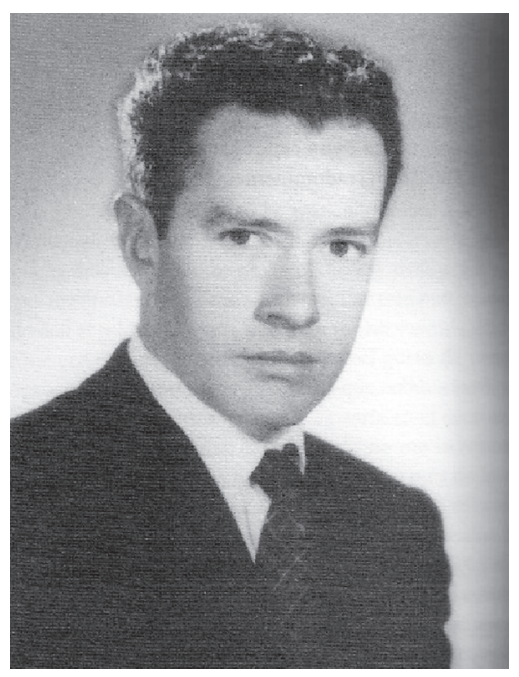

En tercer lugar, la confesión en Rulfo se da también a través de fotografías. No es el Rulfo fotógrafo que se ha redescubierto con más de cuatro mil imágenes capturadas por su afición por la fotografía, sino las fotos que acompañaban las cartas a Clara y en las cuales siempre buscaba inmortalizar su faz, su cuerpo, en el estado en el que él estuviera. "Tal vez no hayas recibido a la fotografía de tu muchacho (vuelvo al asunto). Y sé que tú comprenderás la razón por la cual no te le he enviado todavía (...) No chachinita, no creas que no te la mandé porque salgo feo. Yo sé que soy re feo. No la cuestión es distinta. Las otras están tan retocadas que ni yo mismo me conozco" (Rulfo, 2012:121). Cada carta es también un retrato, una huella que Clara no puede olvidar, esa cara que Rulfo quiere que su amada guarde en los arcones de su memoria. La fotografía confiesa que ha vivido, que Rulfo ha cambiado, que todavía está flaco, que está enfermo, que muere de amor por su chiquilla adorada.

Finalmente, podríamos detenernos en un rasgo particular que emerge en cada una de las cartas y la forma como Rulfo hereda una escritura epistolar y que concentra la huella de una tradición romántica que sigue latente en muchos fragmentos de las cartas que le escribe y le contesta a Clara Aparicio. Un aspecto fundamental en la mayoría de las cartas, es el recurso poético del lenguaje en combinación con la experiencia de lo oral que más tarde va a ser significativa en obras como Pedro Páramo. Rulfo recurre a una escritura íntima donde devela lo que siente por Clara y a la vez poetiza el amor, lo nombra a su manera, hace de él un objeto de reflexión permanente. Es innegable que Rulfo ama, que el amor es un verbo para el mexicano y que estar enamorado es una condición que lo redime en medio de las turbulencias. Rulfo le expresa a Clara que "Yo pondría mi corazón entre tus manos sin que él se revelara/No tendría ni así de miedo, porque sabría 
quién lo tomaba/ Y un corazón que sabe y que presiente cuál es la mano amiga, manejada por otro corazón, no teme nada/ ¿Y qué mejor amparo tendría él, que esas tus manos Clara?" (Rulfo 2012:21).

Pareciera que esos sietes años de amor entre Juan Rulfo y Clara Aparicio, tuviera esa característica de los amores del siglo XIX, donde la carta es por excelencia el vehículo emocional de los amantes.
Pero hay una característica interesante en estas cartas y es que la mayoría son respuestas a cartas que Clara le había enviado a Rulfo en su estadía en México. A lo que no podemos acceder es a la voz de Clara Aparicio, pero si se puede comprender de parte de Rulfo como hay una periodicidad en la llegada de las misivas, qué le dice Clara, qué le contesta Juan Rulfo, qué noticias sabe Rulfo de Guadalajara, qué eventos familiares sucede en casa de los Aparicio, entre otros asuntos importantes y que se convierten en materia prima para la escritura de las cartas de vuelta. Se podría afirmar de manera atrevida, que hay una reciprocidad en el amor que tanto Juan como Clara sienten, amor que durante siete años está mediado por los sordos poderes de las cartas de amor, cartas a su Mayecita, a su madrinita, a su chiquilla, a su mujercita adorada.

\section{Referencias}

Bachelard, G. (2005). El derecho de soñar México: Fondo de cultura económica,

Bachelard, G. (2000). La poética del espacio. Argentina: Fondo de cultura económica.

De la Cruz, Juan. Llama de amor viva. Recuperado 12/05/2013: http://www.e-torredebabel.com/Biblioteca/San-Juan-Cruz/Llama-Amor-Viva.htm.

Bécquer, Gustavo Adolfo. Cartas desde mi celda. Recuperado 12/05/2013: http://books.google.com.co/ books?id=2wY19_wqGTAC\&printsec $=$ frontcover\&dq $=$ cartas + desde + mi + celda\&hl $=$ es\&sa $=$ X\&ei $=$ mbKeUa-FDJKA9QSTmICQAQ\&ved=0CC8Q6AEwAA.

Kundera, M. (2000). La ignorancia. Barcelona: Tusquets editores.

Paz, O. (2012) El laberinto de la soledad. México: Fondo de cultura económica.

Ricardo, O. (1985). "El habla hablada divagaciones sobre un recurso estilístico". THESAURUS. Tomo XL. Núm. 1

Rulfo, J (2012). Cartas a Clara. México: Editorial RM.

Jiménez, V. Vital, A. Zepeda, J (2006). Tríptico para Juan Rulfo. México: Editorial RM

Zambrano, M. (2004) La confesión género literario. España: Editorial Siruela. 